\title{
Myocyte-Specific Enhancer Factor 2C
}

National Cancer Institute

\section{Source}

National Cancer Institute. Myocyte-Specific Enhancer Factor 2C. NCI Thesaurus. Code C92163.

Myocyte-specific enhancer factor $2 \mathrm{C}(473 \mathrm{aa}, \sim 51 \mathrm{kDa})$ is encoded by the human MEF2C gene. This protein plays a role in the regulation of cardiac development, myogenesis and blood vessel development. 